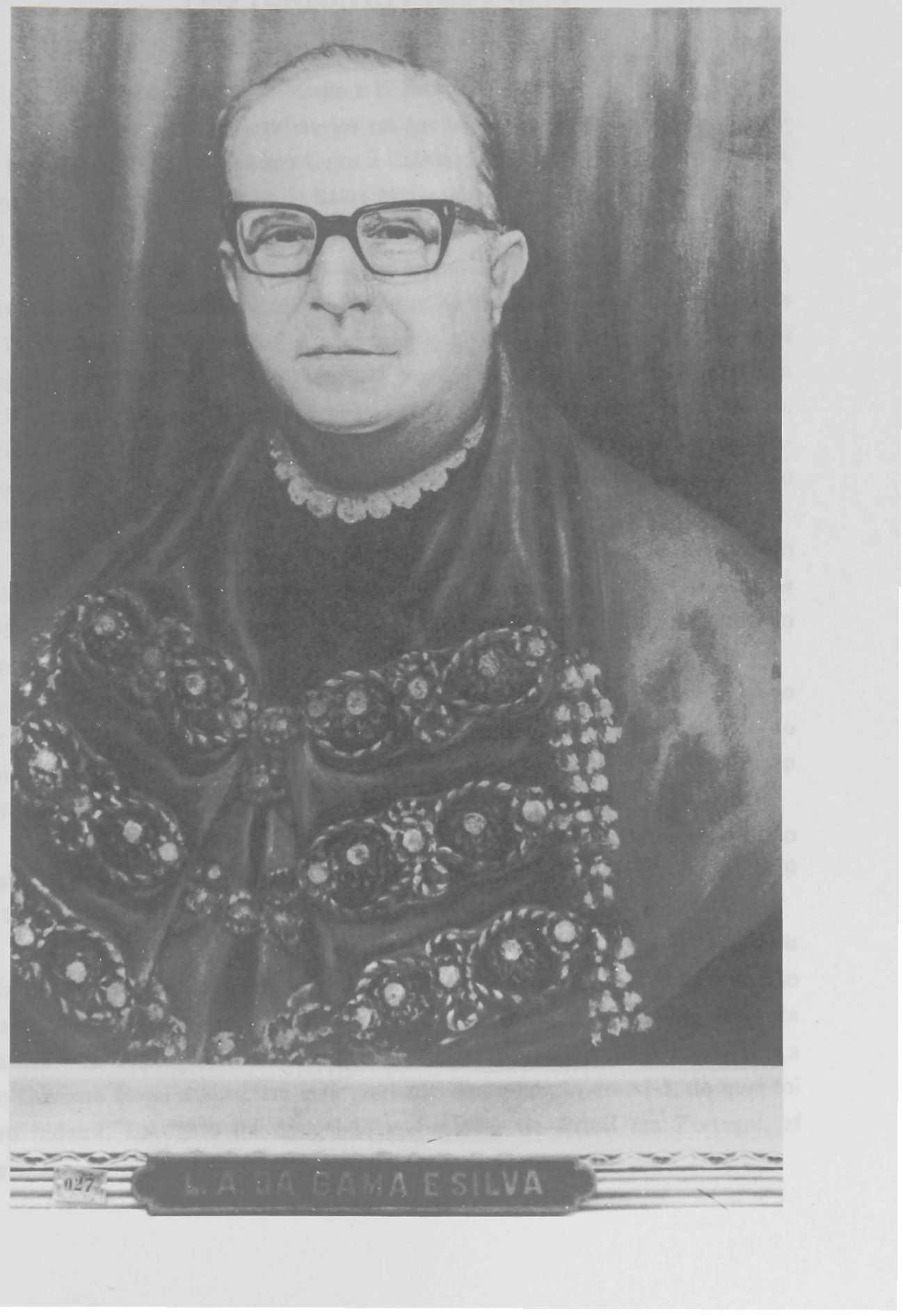





\section{LUIZ ANTONIO DA GAMA E SILVA}

(1959-1962)

Nasceu em Mogi-Mirim a 19 de maio de 1913.

Fez os estudos primários em sua terra natal e os primeiros exames do curso secundário no Ginásio Culto à Ciência, de Campinas, matriculando-se depois, no Ginásio Diocesano de Santa Maria, da mesma cidade, onde concluiu, em 1929, o curso ginasial.

Em 1930, matriculou-se na Faculdade de Direito de São Paulo, recebendo o grau de bacharel em Ciências Jurídicas e Sociais em janeiro de 1934. Dedicou-se, desde logo, à advocacia e à política, filiando-se ao Partido Republicano Paulista e como jornalista ingressou no Correio Paulistano. Em 1935, durante alguns meses, foi promotor público interino em Mogi-Mirim. Lecionou as cadeiras de Língua Portuguesa e Lógica nos Colégios Liceu PanAmericano, Colégio Carlos Gomes e Colégio Rio Branco, na capital de São Paulo.

Em novembro de 1944, foi nomeado livre-docente de Direito Internacional Privado, ocasião em que recebeu o grau de doutor em Direito. Em 1953 concorreu à cátedra da mesma disciplina, tendo sido aprovado unanimemente.

De 1938 a 1945, foi juiz do Tribunal de Impostos e Taxas do Estado de São Paulo. Pertenceu à Associação Brasileira de Direito Internacional, ao Instituto dos Advogados de São Paulo e exerceu o cargo de diretor do Centro das Indústrias de São Paulo.

Em 1956 assumiu a vice-diretoria da Faculdade de Direito de São Paulo, sendo nomeado diretor interino, de 1958 a 1959, e diretor efetivo, de 1959 a 1962.

Em 1964 foi eleito juiz da Côrte Permanente de Arbitragem de Haia, com mandato até 1976. De 1963 a 1967, foi reitor da Universidade de São Paulo. No ano de 1964, já no governo revolucionário, foi nomeado ministro da Justiça e da Educação e Cultura e, posteriormente, em 1967, ministro da Justiça no Governo Costa e Silva, em cuja gestão se deu a edição do AI-5, do qual foi seu redator. Em 1970 foi designado embaixador do Brasil em Portugal, aí permanecendo até 1974. 
Participou de inúmeros congressos e conferências, publicou regularmente artigos em jornais e revistas jurídicas especializadas, além das obras que seguem.

Faleceu a 2 de fevereiro de 1979.

\section{Obras Publicadas}

A ordem pública em direito internacional privado. São Paulo : s.c.p., 1944. Tese (livre-docente). Faculdade de Direito da USP.

As qualificações em direito internacional privado. São Paulo : s.c.p., 1952. Tese (catedrático). Faculdade de Direito da USP.

Casamento: estrangeiros casados sob o regime de separação de bens; comunhão dos adquiridos na constância do matrimônio: parecer. Revista dos Tribunais, São Paulo, v. 257, p. 86-99, 1957. 